
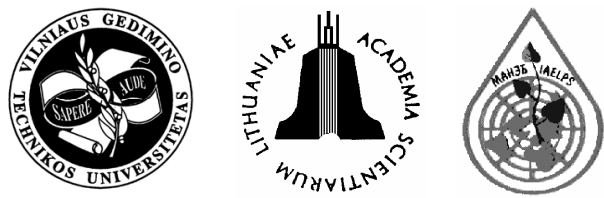

\title{
EVALUATION OF LITHUANIAN AIR QUALITY MONITORING DATA APPLYING SYNOPTICAL ANALYSIS
}

\author{
Vilma Bimbaité ${ }^{1}$, Raselè Girgždiené2 \\ ${ }^{1}$ Dept of Environmental Protection, \\ ${ }^{2}$ Dept of Physics, Vilnius Gediminas Technical University, \\ Sauletekio al. 11, LT-10223 Vilnius, Lithuania \\ E-mail: ${ }^{1}$ bimbaite_03@yahoo.com; ${ }^{2}$ rasele.girgzdiene@fm.vtu.lt \\ Submitted 14 Mar 2007; accepted 3 Apr 2007
}

\begin{abstract}
Relationship between synoptical patterns and different pollutants was analysed in the study. Cases with ozone concentrations higher or equal to the 95th percentile of monthly ozone concentrations were analysed over the period 2002-2005. Ozone concentration cases were grouped into seven concentration intervals and analysed according to synoptical patterns (cold, warm and occluded fronts). Relationship between $\mathrm{SO}_{2}, \mathrm{SO}_{4}$ and $\mathrm{NO}_{2}$ and synoptical objects was analysed during warm and cold seasons.

The influence of cold, warm and occluded fronts on the high ozone level formation are very similar at both Lithuanian rural stations of Preila and Rūgšteliškès. The influence of all the fronts was more significant during night hours at a relatively low $\left(50-100 \mu \mathrm{g} / \mathrm{m}^{3}\right)$ and high $\left(>100 \mu \mathrm{g} / \mathrm{m}^{3}\right)$ ozone levels during day hours.

The concentrations of gaseous $\mathrm{SO}_{2}, \mathrm{NO}_{2}$ and aerosol $\mathrm{SO}_{4}$ pollutants for the cases with hourly ozone concentration values $\geq 95$ th percentile were analysed. The influence of different synoptical patterns was found to be stronger during a warm season and lower during a cold season of the year.
\end{abstract}

Keywords: synoptical patterns, air quality, front, cyclone, anticyclone, ozone, $\mathrm{SO}_{2}, \mathrm{SO}_{4}, \mathrm{NO}_{2}$.

\section{Introduction}

Air quality, concentration of air pollutants is influenced not only by physical and chemical processes but also by synoptical situation and meteorological processes as well as geographical and social factors. Air quality also depends on whether the pollutants will accumulate in the emission place or they will be dispersed in a larger area [1]. Thereby synoptical and meteorological conditions have a significant influence on air quality. Moreover, synoptical objects such as cyclones, anticyclones and others can significantly determine pollutant transport from one part of the world to the other parts (transboundary transport). There is a particular concern that rising emissions in regions with growing industrialization could offset the positive effects on regional air quality of emission reductions made in other parts of the world [2]. Nevertheless, the emissions and simultaneously concentrations of different pollutants are decreasing in Europe [3] as well as in Lithuania [4, 5], during the last 20 years the concentrations during some episodes could be high. According to the authors, a high pollutant level is often related with a long-range or intercontinental transport. Similar results were also obtained at other stations in Europe [6]. Since 1980 the background monitoring station of Preila (EMEP station), and since 1994 other stations of Aukštaitija (Rūgšteliškès), Žemaitija (Plateliai) regions were established in Lithuania [1]. The measure- ments of the concentration of the main pollutants as ozone, sulphur and nitrogen dioxides, sulphates, heavy metals, nitrates and ammoniums are carried out at these stations. The meteorological parameters as the amounts of precipitation, air and soil temperature, wind direction and speed, sun irradiation [7] are observed too. Monitoring stations belong to the international station network; thereby their observations are strictly regulated by common European requirements $[8,9]$.

Relationship between air quality and meteorological parameters and synoptical conditions are often analysed in cities or big industrial centers [10-14]. Such investigations let to know the main regularity about the relationship between weather conditions and pollution level. Relationship between pollution and meteorological parameters is clearer than with synoptical patterns. It is already known that by weak wind or calm conditions, i e, temperature inversion which is mainly observed during cloudless weather, make favorable situation for the accumulation of pollutants near the ground surface and, herewith, the air pollution level in such conditions could increase significantly [15]. Such complexes of meteorological parameters are common to anticyclones. Favorable conditions for the dispersion of pollutants dominate when weather is determined by cyclones, because a lowpressure atmospheric circulation determines stronger winds, more frequent and intensive precipitation that disperses or removes damaging admixtures. 
The formation of synoptical patterns is very complex and difficult. During the passage of any synoptical pattern regional meteorological conditions change rapidly [16, 17], especially in the case of fronts. During the passage of a cold front (transition zone where a cold air mass replaces a warmer air mass) temperatures can drop by more than 15 degrees within the first hour. When a warm front (transition zone where a warm air mass replaces a cold air mass) passes, the temperature rises, and the air becomes more humid. Within the passage of an occluded (occlusion) front (when a cold front overtakes a warm front in the developing cyclone) changes can occur in temperature, dew point temperature and wind direction. Anticyclone is a region of a high atmospheric pressure, whereas cyclone is atmospheric pressure distribution in which there is a low central pressure relative to the surrounding pressure [16]. These pressure systems also determine the specific meteorological conditions.

The aim of this study is to evaluate statistically the relationship between concentrations of air pollutants ozone, sulphur oxides and nitrogen dioxide - and synoptical patterns (fronts, cyclones, anticyclones).

\section{Methodology of the investigation}

\subsection{Data basis}

The data basis from two background stations Preila and Rūgšteliškès - was taken for the analysis. The station of Preila $\left(55^{\circ} 22^{\prime} \mathrm{N}\right.$ and $\left.21^{\circ} 02^{\prime} \mathrm{E}\right)$ is located in West Lithuania on the coast of the Baltic Sea, on the Curonian Spit. Rūgšteliškès environmental monitoring station is situated in Aukštaitija region in East Lithuania $\left(55^{\circ} 26^{\prime} \mathrm{N}\right.$ and $\left.26^{\circ} 04^{\prime} \mathrm{E}\right)$ and surrounded by forests. The distance between these two stations is about $350 \mathrm{~km}$. Both stations are located far from local pollution sources.

The hourly ozone concentration data from both environmental monitoring stations were chosen for the period of four years - from 2002 to 2005 . The synoptical information was obtained from the regional synoptical maps. These maps were studied and taken from the Lithuanian Hydrometeorological Service. Data about synoptical patterns, such as cyclones, anticyclones, warm, cold and occluded fronts, were collected. As in the regional synoptical maps only meteorological stations are marked, the nearest stations to the monitoring stations of Preila and Rūgšteliškès were chosen - Klaipèda and Utena stations, according to that the synoptical situation was estimated.

Meteorological parameters as wind speed and direction, air temperature and amounts of precipitation were obtained from Preila and Rūgšteliškès stations.

Pollutant data of sulphur dioxides $\left(\mathrm{SO}_{2}\right)$, sulphate $\left(\mathrm{SO}_{4}\right)$ and nitrogen dioxide $\left(\mathrm{NO}_{2}\right)$ were analysed from Preila station for the period 2002-2004. $\mathrm{SO}_{2}, \mathrm{SO}_{4}, \mathrm{NO}_{2}$ 24-hour averaged concentration data were taken from the official website of EMEP (Co-operative Programme for Monitoring and Evaluation of the Long-range Transmission of Air Pollutants in Europe) [18].

\subsection{Methodology}

Preila and Rūgšteliškès stations were chosen in order to compare the relationship between the highest pollution level and synoptical patterns as well as meteorological parameters in the Lithuanian regions with different background. As the distance between these stations is about $350 \mathrm{~km}$, it is obvious that different synoptical and meteorological conditions can affect air quality in the surroundings of these stations at the same time.

Hourly ozone concentration data and their percentiles were chosen as the baseline for analysis. The $95^{\text {th }}$ percentiles of ozone concentrations were calculated for separate months. Such concentrations $\left(\geq 95^{\text {th }}\right.$ percentile) were chosen in order to expand the amount of data suitable for further analysis. For the first step, the days with ozone concentration equal to or higher than the $95^{\text {th }}$ percentile were selected for further analysis. As the amount of data after such sorting was still very large, an additional essential criterion was chosen to select final ozone data for further investigation: the ozone hourly value $\geq 95$ th percentile should be measured four and more hours per day.

Synoptical data were analysed only according to the date and time of already chosen ozone concentration cases. The same principle was applied for the meteorological data from both stations as well.

Daily concentration data for the other pollutants $\left(\mathrm{SO}_{2}, \mathrm{SO}_{4}, \mathrm{NO}_{2}\right)$ were also selected according to the ozone concentration case dates, $\mathrm{i}$ e, for the same days independent of the concentration of these pollutants.

Synoptical data of the analysed period (2002-2005) were grouped into five main groups - cases when cyclone, anticyclone and front (warm, cold, occlusion) activity was determined. Then episodes with a different type of atmospheric circulation were analysed separately. In order to exclude seasonal ozone variations the ozone concentrations were grouped into seven intervals every $10 \mu \mathrm{g} / \mathrm{m}^{3}$ from 50 to $120 \mu \mathrm{g} / \mathrm{m}^{3}$ and above. Data from both stations were analysed and compared.

Data of the other pollutants $\left(\mathrm{SO}_{2}, \mathrm{SO}_{4}, \mathrm{NO}_{2}\right)$ were also grouped according to synoptical patterns and analysed for the whole period 2002-2004. The averaged pollutant concentrations during the event were compared with the monthly average.

\section{Results}

In pursuance of the above-mentioned criteria, the number of cases, acceptable for further investigation, was determined. A different number of appropriate events during separate years was found in both stations of Preila and Rūgšteliškès (Table 1).

Table 1. Number of analysed events at the background stations in Lithuania in 2002-2005

\begin{tabular}{l|c|c|c|c}
\hline Station & 2002 & 2003 & 2004 & 2005 \\
\hline Preila & 66 & 66 & 67 & 86 \\
\hline Rūgšteliškès & 84 & 82 & 95 & 87 \\
\hline
\end{tabular}


Table 2. The 95th percentile and maximum of ozone concentration in $\mu \mathrm{g} / \mathrm{m}^{3}$ and the number of selected cases at Preila station in 2002-2005

\begin{tabular}{|c|c|c|c|c|c|c|c|c|c|c|c|c|}
\hline \multirow[b]{2}{*}{ 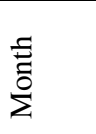 } & \multicolumn{3}{|c|}{2002} & \multicolumn{3}{|c|}{2003} & \multicolumn{3}{|c|}{2004} & \multicolumn{3}{|c|}{2005} \\
\hline & $\begin{array}{l}\text { 95th per- } \\
\text { centile }\end{array}$ & Max & Ü & $\begin{array}{l}\text { 95th per- } \\
\text { centile }\end{array}$ & Max & లే & $\begin{array}{l}\text { 95th per- } \\
\text { centile }\end{array}$ & Max & Uే & $\begin{array}{l}\text { 95th per- } \\
\text { centile }\end{array}$ & Max & Uే \\
\hline Jan & 71,8 & 78,4 & 7 & 70,3 & 78,8 & 6 & 68,2 & 75,1 & 6 & 75,14 & 81,5 & 6 \\
\hline $\mathrm{Feb}$ & 77,3 & 81,7 & 6 & 93,5 & 102,5 & 5 & 78,5 & 83,8 & 7 & 88,0 & 97,6 & 8 \\
\hline March & 83,6 & 97,6 & 5 & 103,8 & 136,1 & 5 & 93,7 & 104,6 & 5 & 112,8 & 148,4 & 5 \\
\hline April & 105,5 & 118,5 & 4 & 110,4 & 145,7 & 8 & 101,6 & 129,2 & 5 & 107,9 & 147,3 & 8 \\
\hline May & 104,4 & 107,6 & 4 & 105,4 & 119,0 & 6 & 105,0 & 119,8 & 6 & 113,1 & 138,6 & 8 \\
\hline June & 102,2 & 136,7 & 3 & 102,2 & 137,2 & 6 & 106,4 & 113,9 & 5 & 108,0 & 158,0 & 6 \\
\hline July & 102,2 & 127,0 & 7 & 86,5 & 93,6 & 2 & 94,9 & 114,0 & 6 & 113,7 & 134,4 & 7 \\
\hline Aug & 106,9 & 143,7 & 4 & 88,7 & 108,2 & 4 & 98,2 & 124,6 & 5 & 96,14 & 134,8 & 9 \\
\hline Sept & 91,4 & 122,0 & 8 & 93,6 & 142,4 & 5 & 95,3 & 106,4 & 6 & 88,6 & 113,3 & 7 \\
\hline Oct & 60,5 & 62,7 & 4 & 62,8 & 67,7 & 7 & 67,6 & 77,0 & 5 & 107,8 & 118,4 & 7 \\
\hline Nov & 57,4 & 64,9 & 7 & 51,2 & 66,0 & 7 & 75,4 & 87,9 & 5 & 73,1 & 95,9 & 7 \\
\hline Dec & 66,4 & 71,9 & 7 & 63,5 & 67,6 & 5 & 72,20 & 74,80 & 6 & 64,10 & 67,6 & 8 \\
\hline
\end{tabular}

Table 3. The 95th percentile and maximum of ozone concentration in $\mu \mathrm{g} / \mathrm{m}^{3}$ and the number of selected cases at Rūgšteliškès station in 2002-2005

\begin{tabular}{|c|c|c|c|c|c|c|c|c|c|c|c|c|}
\hline \multirow[b]{2}{*}{$\begin{array}{l}\bar{E} \\
\stackrel{\bar{\Xi}}{\Sigma}\end{array}$} & \multicolumn{3}{|c|}{2002} & \multicolumn{3}{|c|}{2003} & \multicolumn{3}{|c|}{2004} & \multicolumn{3}{|c|}{2005} \\
\hline & $\begin{array}{l}\text { 95th per- } \\
\text { centile }\end{array}$ & Max & ש్ & $\begin{array}{l}\text { 95th per- } \\
\text { centile }\end{array}$ & Max & Uే & $\begin{array}{l}\text { 95th per- } \\
\text { centile }\end{array}$ & Max & Uే & $\begin{array}{l}\text { 95th per- } \\
\text { centile }\end{array}$ & Max & Uే \\
\hline Jan & 65,4 & 79,3 & 9 & 68,6 & 74,8 & 11 & 54,6 & 57,4 & 10 & 71,9 & 79,0 & 8 \\
\hline Feb & 66,4 & 71,8 & 8 & 80,8 & 89,0 & 6 & 87,0 & 91,5 & 9 & 76,5 & 88,8 & 4 \\
\hline March & 81,4 & 91,1 & 7 & 113,2 & 132,3 & 8 & 98,8 & 110,1 & 7 & 122,0 & 144,2 & 5 \\
\hline April & 114,6 & 132,2 & 6 & 116,2 & 137,2 & 8 & 108,9 & 124,7 & 6 & 127,5 & 168,8 & 7 \\
\hline May & 108,5 & 123,4 & 6 & 101,7 & 119,1 & 7 & 107,0 & 121,5 & 8 & 114,9 & 166,8 & 8 \\
\hline June & 92,9 & 100,5 & 7 & 92,0 & 118,2 & 3 & 101,9 & 108,5 & 7 & 97,2 & 114,9 & 5 \\
\hline July & 102,4 & 142,7 & 7 & 83,8 & 96,0 & 5 & 91,6 & 96,7 & 9 & 93,3 & 117,5 & 6 \\
\hline Aug & 117,0 & 165,2 & 6 & 73,9 & 84,7 & 5 & 89,6 & 114,7 & 7 & 95,7 & 113,5 & 8 \\
\hline Sept & 90,9 & 116,3 & 8 & 74,7 & 91,8 & 6 & 78,8 & 98,1 & 8 & 99,1 & 122,2 & 10 \\
\hline Oct & 60,8 & 68,7 & 6 & 56,4 & 59,5 & 6 & 67,3 & 87,7 & 10 & 74,8 & 92,7 & 7 \\
\hline Nov & 54,6 & 65,3 & 6 & 47,7 & 52,6 & 9 & 68,4 & 82,6 & 5 & 59,6 & 78,5 & 10 \\
\hline Dec & 61,7 & 66,7 & 6 & 59,8 & 64,5 & 8 & 72,0 & 81,7 & 9 & 60,0 & 64,5 & 9 \\
\hline
\end{tabular}

It should be noted that the number of cases was found to be different not only during years but separate months as well. Moreover, their number was different comparing both stations (Tables 2, 3). This could be explained by particular geographical conditions, as the stations are located at a distance of $300 \mathrm{~km}$ from each other. Rather often the eastern and western parts of Lithuania are influenced by different synoptical situations. The $95^{\text {th }}$ percentiles of ozone value during separate months were calculated (Tables 2, 3).

On the average, the distribution between days with cyclones and anticyclones in Lithuania is 60 and $40 \%$ during the year, respectively [19]. The results of the assessment of synoptical situation during our investigation, when ozone concentrations were higher than the $95^{\text {th }}$ percentile, show that $152(43,7 \%)$ cases with the influence of anticyclonic circulation and 196 (56,3\%) cases with cyclonic circulation were observed at Rugšteliškès station during the analysed period 2002-2005. 123 $(41,1 \%)$ cases with the influence of anticyclonic circulation and $176(58,9 \%)$ cases with cyclonic circulation were found in Preila station during the same period.

Frontal circulation is the main factor that influences and, it could be even said, forms the weather conditions in Lithuania. In the investigations $[12,15,20,21]$ the influence of fronts on the concentrations of ozone and other pollutants like $\mathrm{NO}_{2}$ was demonstrated. For this reason, we analysed which influence could have different front's patterns on the pollutant level at the background stations. $46(13 \%)$ cases were found with a warm front, $68(19,5 \%)$ cases - with a cold front and $41(11,7 \%)$ case - with an occluded front at Rugšteliškès station during the period 2002-2005 when ozone concentrations were higher than the $95^{\text {th }}$ percentile. Close results were found at Preila station: $46(15 \%)$ cases with a warm front, $57(19 \%)$ cases with a cold front and $51(17 \%)$ case with an occluded front during the period 2002-2005.

It is known [22] that the highest ozone concentrations are observed mostly during day hours because ozone variations have a diurnal course. However, sometimes the highest ozone level is measured not in the afternoon but during night hours. Mostly it occurs during the passage of cold or warm fronts. It was evaluated that the distribution of cases with ozone concentration equal to or higher than the $95^{\text {th }}$ percentile during the daytime $(8 \mathrm{a} \mathrm{m}-8 \mathrm{p} \mathrm{m})$ and at night $(8 \mathrm{p} \mathrm{m}-8 \mathrm{a} \mathrm{m})$ at both stations over the investigated period. 


\section{1. $\mathrm{O}_{3}$ concentrations during a cold front}

The obtained results show that $50 \%$ of cases with maximum ozone concentration in the interval $50-70 \mu \mathrm{g} / \mathrm{m}^{3}$ at the monitoring station of Preila were determined during night hours (Fig 1). These values are typical especially during October and December when cyclonic circulation is very frequent. At Rūgšteliškès monitoring station the situation is very similar - only 6 from 13 cases happened during the night time. Also, they were determined during the cold seasons (October - February).

More cases with the concentration level in the interval $50-70 \mu \mathrm{g} / \mathrm{m}^{3}$ were found at Rūgšteliškès station than at Preila station, 6 and 13 cases, respectively.

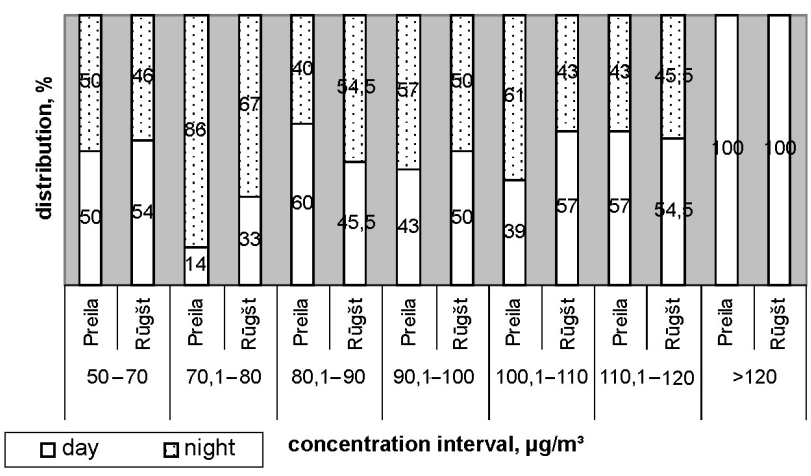

Fig 1. Distribution of cases with cold front at different ozone concentration intervals in Preila and Rūgšteliškès during day and night hours

During a cold front in both stations of Preila and Rūgšteliškès ozone concentrations in the interval 70,1$80 \mu \mathrm{g} / \mathrm{m}^{3}$ were more frequent during night hours. In Preila there were 6 cases from 7, and in Rūgšteliškès -4 from 6 cases. In Preila all these cases in the interval 70,1$80 \mu \mathrm{g} / \mathrm{m}^{3}$ were determined during cold seasons (OctoberFebruary except November). In Rūgšteliškès only $50 \%$ of cases occurred during cold months, while the others were determined during August and September.

In the interval $80,1-90 \mu \mathrm{g} / \mathrm{m}^{3}$ at Preila station 2 from five cases of extreme ozone concentrations were determined during night hours, whereas in Rūgšteliškès 6 from 11 cases were ascertained during these hours. It could be said that all the cases in Preila were during a cold period of the year. Whereas in Rūgšteliškès such ozone concentrations were mainly determined during September and October, but there were also cases in July, August and February. The ozone interval $80,1-90 \mu \mathrm{g} / \mathrm{m}^{3}$ was associated with a cold front more often in Rūgšteliškès than in Preila, 11 and 5 cases, respectively.

4 from 7 cases of ozone concentrations in the interval $90.1-100 \mu \mathrm{g} / \mathrm{m}^{3}$ in Preila, and 6 from 12 cases in Rūgšteliškès were determined during the night. No monthly or seasonal distribution of these cases was observed in both stations, i e, they could be noticed every month. A cold front determines ozone concentrations in the interval $90,1-100 \mu \mathrm{g} / \mathrm{m}^{3}$ for 7 cases in Preila, and for 12 cases in Rūgšteliškès.

In Preila extreme ozone concentrations during a cold front in the interval $100,1-110 \mu \mathrm{g} / \mathrm{m}^{3}$ were mainly dis- tributed during evening and night hours -8 cases from 13. Whereas at Rūgšteliškès monitoring station only 3 from 7 cases were determined during night hours.

Talking about the observed ozone values in this interval's during separate months it could be mentioned that they were mainly determined during a warm season. It could be unusual to take October as a warm season, because normally it is already a cold season, but such a situation was ascertained during October of 2005. In September and October of 2005 a temperature anomaly was observed, it was higher than a long-term monthly average value.

In contrast to the above mentioned cases, the extreme ozone concentrations (interval 110,1-120 $\mu \mathrm{g} / \mathrm{m}^{3}$ ) related with a cold front at both stations were determined mostly in the daytime. 4 from 7 cases were ascertained in Preila, and 6 from 11 cases - in Rūgšteliškès. If we take the condition that October of 2005 was a month of a warm season (because of the temperature anomaly described above), then the cases of maximum ozone concentrations in the interval 110,1-120 $\mu \mathrm{g} / \mathrm{m}^{3}$ were determined during a warm season. It should be noted that more cases with a cold front were ascertained in Rūgšteliškès than in Preila - respectively, 11 and 7.

Extreme ozone concentrations were determined both at Preila and Rūgšteliškès monitoring stations during afternoon hours and during a warm season. 10 cases with concentrations above $120 \mu \mathrm{g} / \mathrm{m}^{3}$ were determined in Preila, and 8 ones - in Rūgšteliškès.

\section{2. $\mathrm{O}_{3}$ concentrations during a warm front}

In the interval $50-70 \mu \mathrm{g} / \mathrm{m}^{3} 5$ from 10 cases of ozone concentrations $\geq 95^{\text {th }}$ percentile were determined during night hours at the passage of a warm front at Preila monitoring station. 9 from 19 cases occurred during night hours at Rūgšteliškès station. Seasonal distribution of cases is very clear - all of them were ascertained during a cold season. In the interval $50-70 \mu \mathrm{g} / \mathrm{m}^{3} 19$ cases were found in Rūgšteliškès and 10 ones in Preila during the passage of a warm front.

In the interval $70,1-80 \mu \mathrm{g} / \mathrm{m}^{3}$ during night hours 2 cases from 5 of ozone concentrations were determined in Preila, and 1 from 6 cases - in Rūgšteliškès. Distribution of cases between seasons is uneven at both stations. In Preila all of them were ascertained during October and December, at that time in Rūgšteliškès 1 case was found in August, and others - during a cold season.

At both monitoring stations of Preila and Rūgšteliškès the same number of cases with ozone concentrations in the interval $80,1-100 \mu \mathrm{g} / \mathrm{m}^{3}$ was ascertained (Fig 2). Moreover, 3 from 5 of these cases were determined during night hours at both stations. Seasonal distribution of ozone concentration cases during a warm front in the interval $80,1-100 \mu \mathrm{g} / \mathrm{m}^{3}$ can't be dated only to cold or warm seasons. There were cases in both of them.

In the interval $100,1-110 \mu \mathrm{g} / \mathrm{m}^{3} 7$ from 10 cases of ozone concentrations were determined in Preila during night hours, whereas in Rūgšteliškès all the cases were ascertained during day hours (Fig 2). At both monitoring stations the cases with the ozone concentrations in the analysed interval were determined during a warm season. 


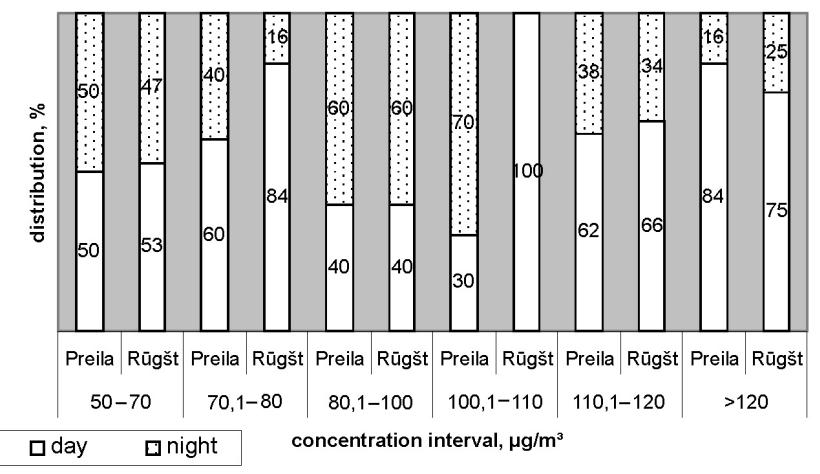

Fig 2. Distribution of cases with warm front at different ozone concentration intervals in Preila and Rūgšteliškès during day and night hours

It should be noted that there were more cases in Preila (10 cases) than in Rūgšteliškès (4 cases).

During the passage of a warm front in the interval $110,1-120 \mu \mathrm{g} / \mathrm{m}^{3}$ of ozone concentrations the biggest part of cases was estimated during the daytime at both monitoring stations of Preila and Rūgšteliškès (Fig 2). Only at Preila station two cases were ascertained in the morning hours. Seasonal distribution of the cases in this interval is analogous at both stations - most cases were ascertained during a warm season.

Hourly distribution of the cases with ozone concentrations $>120 \mu \mathrm{g} / \mathrm{m}^{3}$ was during day hours, and in more concrete afternoon hours both at Preila and Rūgšteliškès monitoring stations. The seasonality of the cases during a warm front in Preila and Rūgšteliškès is comparable and was ascertained during spring and summer months.

\section{3. $\mathrm{O}_{3}$ concentrations during an occluded front}

The formation of an occluded front is a much more complex phenomenon than that of a cold or warm fronts. An occluded front joins a cold and warm frontal surfaces. Moreover, an occluded front could be cold or warm, depending on the distribution of cold and warm air in it. In this study an occluded front was analysed as a one-type system.

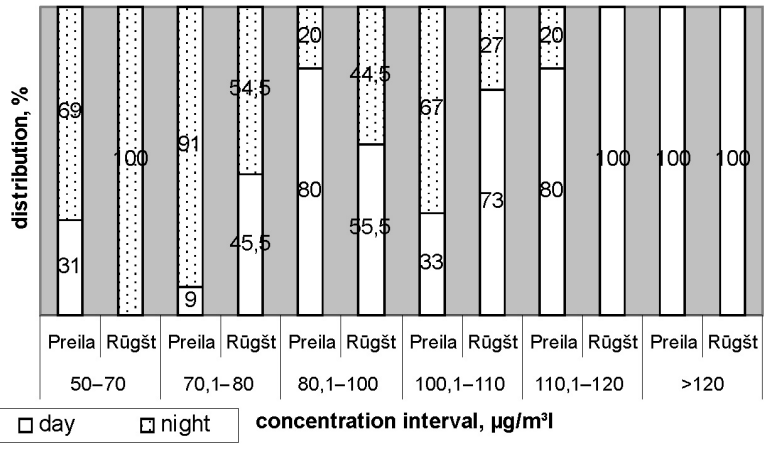

Fig 3. Distribution of cases with occluded front at different ozone concentration intervals in Preila and Rūgšteliškès during day and night hours

In the interval $50-70 \mu \mathrm{g} / \mathrm{m}^{3}$ ozone concentrations both at Preila and Rūgšteliškès monitoring stations were ascertained at night (Fig 3). All the cases during the passage of an occluded front in Rūgšteliškès were determined at night, and in Preila - 9 cases from 13 . Moreover, all the cases at both stations were estimated during a cold season.

During the passage of an occluded front the ozone concentration cases in the interval $70,1-80 \mu \mathrm{g} / \mathrm{m}^{3}$ were estimated mainly at night at both analysed stations (Fig 3). 10 cases from 11 were found in Preila, and 6 cases from 11 were ascertained in Rūgšteliškès at night. All the cases with an occluded front in this interval were determined during cold seasons, $\mathrm{i}$ e in winter and autumn.

The ozone concentration interval $80,1-90 \mu \mathrm{g} / \mathrm{m}^{3}$ was joined with the interval $90,1-100 \mu \mathrm{g} / \mathrm{m}^{3}$ because of very scarce data, it was only two cases at Preila station. In the interval $80,1-100 \mu \mathrm{g} / \mathrm{m}^{3}$ the situation is different from the other two intervals mentioned above. Firstly, here the cases are mainly distributed during the daytime -4 from 5 cases in Preila, and 5 from 9 cases in Rūgšteliškès. Also, in this interval the distribution between seasons aren't so clear, and it could be said that the ozone concentrations in the interval $80,1-100 \mu \mathrm{g} / \mathrm{m}^{3}$ determined by an occluded front are possible during every season except spring.

The seasonal distribution in the interval 100,1$110 \mu \mathrm{g} / \mathrm{m}^{3}$ of ozone concentrations is very definite - all the cases are ascertained during a warm season. The hourly distribution is different at Preila and Rūgšteliškès monitoring stations. 6 from 9 cases in Preila were ascertained during night hours, whereas in Rūgšteliškès - only 3 cases from 11 (Fig 3 ).

The ozone concentrations in the interval 110,1$120 \mu \mathrm{g} / \mathrm{m}^{3}$ were estimated during a warm season. The hourly distribution of the cases differs at the stations. 5 from 10 cases were ascertained at night in Preila, and in Rūgšteliškès all the 11 cases were estimated during day hours.

The extreme ozone concentrations $>120 \mu \mathrm{g} / \mathrm{m}^{3}$ both at Preila and Rūgšteliškès monitoring stations were determined during afternoon hours and during a warm season. 10 cases were assigned to Preila, and 6 ones - to Rūgšteliškès.

\subsection{Influence of synoptical patterns on $\mathrm{NO}_{2}, \mathrm{SO}_{2}$ and $\mathrm{SO}_{4}$ concentrations at Preila monitoring station}

Concentrations of the chemical compounds were estimated according to the obtained results of the ozone level during synoptic patterns, i e, analysis was made only in the days when ozone concentration was higher than the $95^{\text {th }}$ percentile of appropriate months. Consequently, these concentrations were not necessarily extremes. The investigation was made for $\mathrm{NO}_{2}, \mathrm{SO}_{2}$ and $\mathrm{SO}_{4}$ during separate seasons. The pollutant concentration average during a particular synoptical pattern over a separate month was calculated and compared with the threeyear monthly average. The difference was expressed as percentage.

During a cold season in major cases $\mathrm{SO}_{2}$ concentrations did not exceed the three-year monthly mean (Fig 4). Only in the cases of a given occluded (occlusion) front 
and anticyclone they were substantially higher during some months. In the case of a cold front and cyclone a positive deviation from the monthly mean was insignificant, and at a given warm front in all the analysed cases $\mathrm{SO}_{2}$ concentration level didn't exceed the monthly average (Fig 4).

It should be noted that an opposite situation was observed during a warm period, i e, in April - September. $\mathrm{SO}_{2}$ concentration levels in a greater part of cases were higher than the three-year monthly average during a warm season. During the passage of a cyclone and anticyclone this tendency was determined even during 5 from 6 months (Fig 5). In the cases with cold and warm fronts $\mathrm{SO}_{2}$ concentrations higher than the monthly mean were determined, respectively during 3 and 4 from 6 months.

A similar $\mathrm{NO}_{2}$ situation to $\mathrm{SO}_{2}$ concentration distribution was observed during cold and warm seasons. During a cold season $\mathrm{NO}_{2}$ concentration level in most cases, when the ozone level was high, did not exceed the threeyear monthly mean (Fig 6). As in the cases with $\mathrm{SO}_{2}$, the concentration levels of $\mathrm{NO}_{2}$ during a warm season were higher than the three-year monthly mean. At a given cyclone and anticyclone $\mathrm{NO}_{2}$ concentration levels are higher than the monthly mean during the whole warm season (Fig 7). It should be mentioned that $\mathrm{NO}_{2}$ concentrations exceed the three-year monthly average in August for all the cases with the analysed synoptical patterns.

Simultaneous increase of ozone and other gaseous pollutant concentrations under anticyclone conditions over a warm period maybe partly could be explained by existing favorable conditions of photochemical ozone formation with increased emission of other pollutants. Over a cold period a high ozone level was observed only at low $\mathrm{SO}_{2}$ as well as $\mathrm{NO}_{2}$ concentrations, i e, under comparatively clean conditions when other gaseous pollutants do not decay in ozone. This proposition was proved analysing the behavior of $\mathrm{SO}_{4}$, the main part of the aerosol, during the episodes with a high ozone concentration and appropriate synoptical conditions.

\section{$\mathrm{SO}_{2}$ cold season}

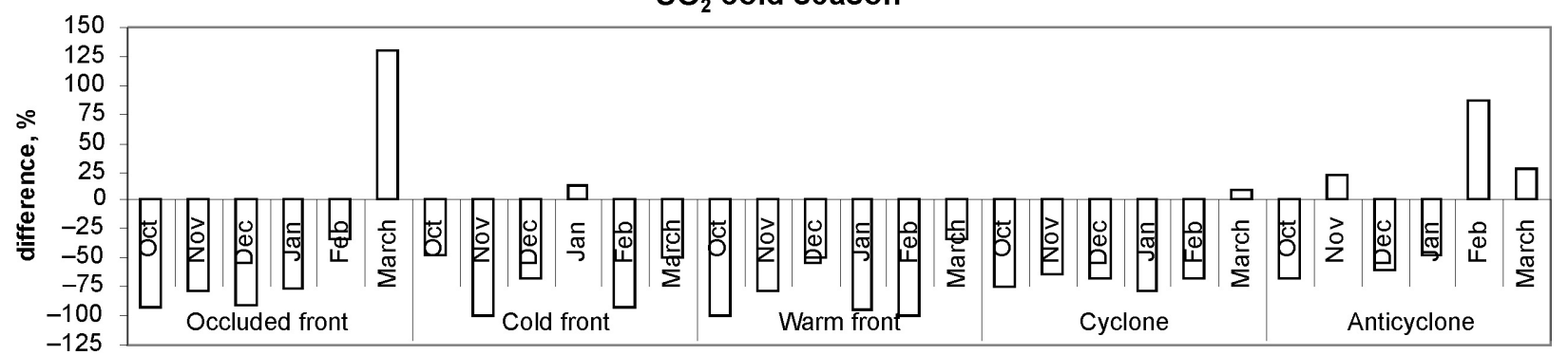

months

Fig 4. Difference between $\mathrm{SO}_{2}$ three-year monthly average and average concentration during cold season at Preila background station

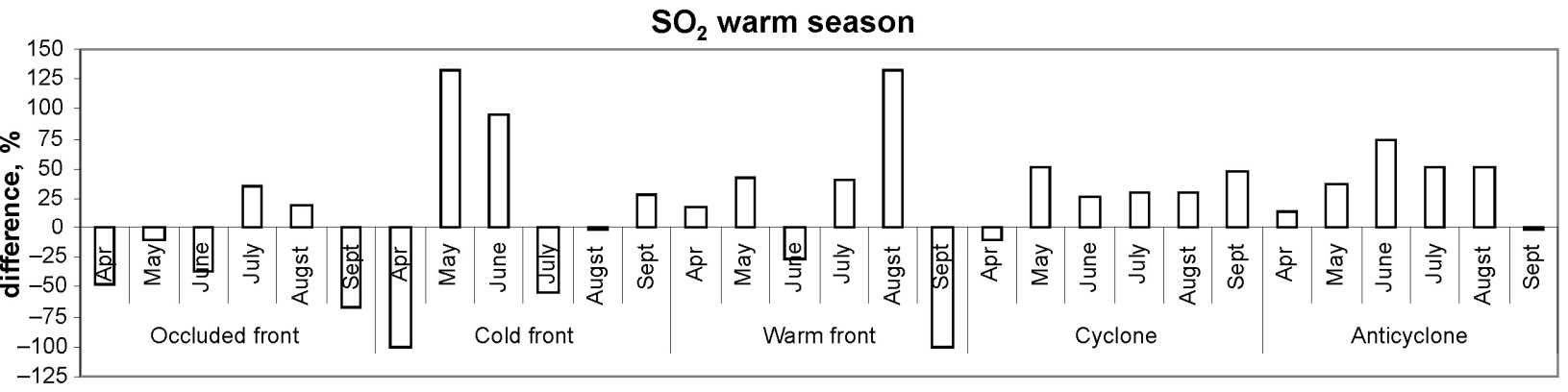

months

Fig 5. Difference between $\mathrm{SO}_{2}$ three-year monthly average and average concentration during warm season at Preila background station

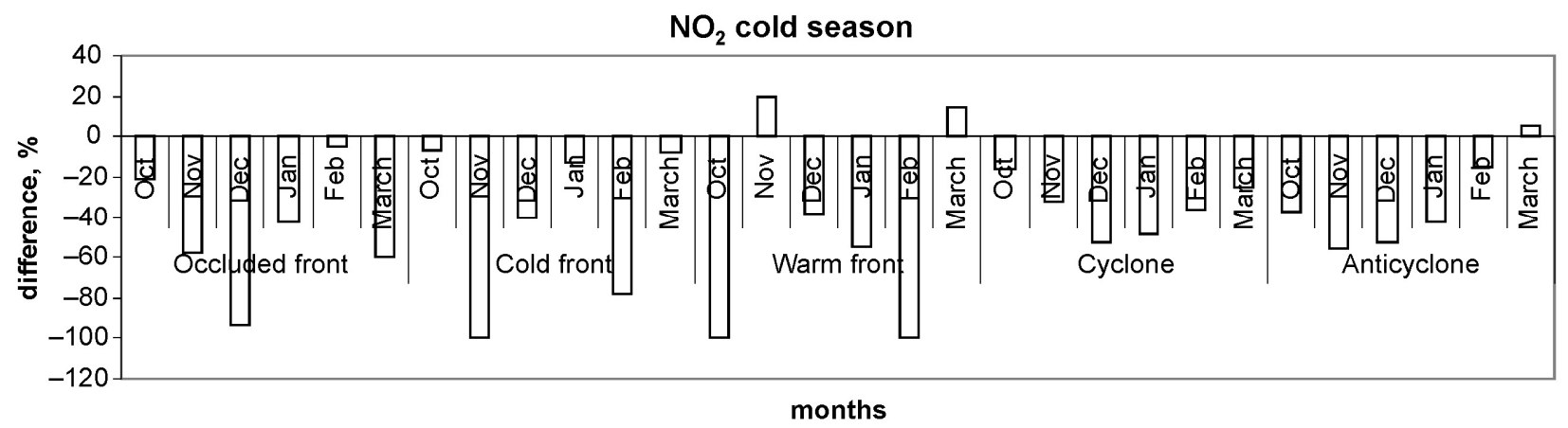

Fig 6. Difference between $\mathrm{NO}_{2}$ three-year monthly average and average concentration during cold season at Preila background station 


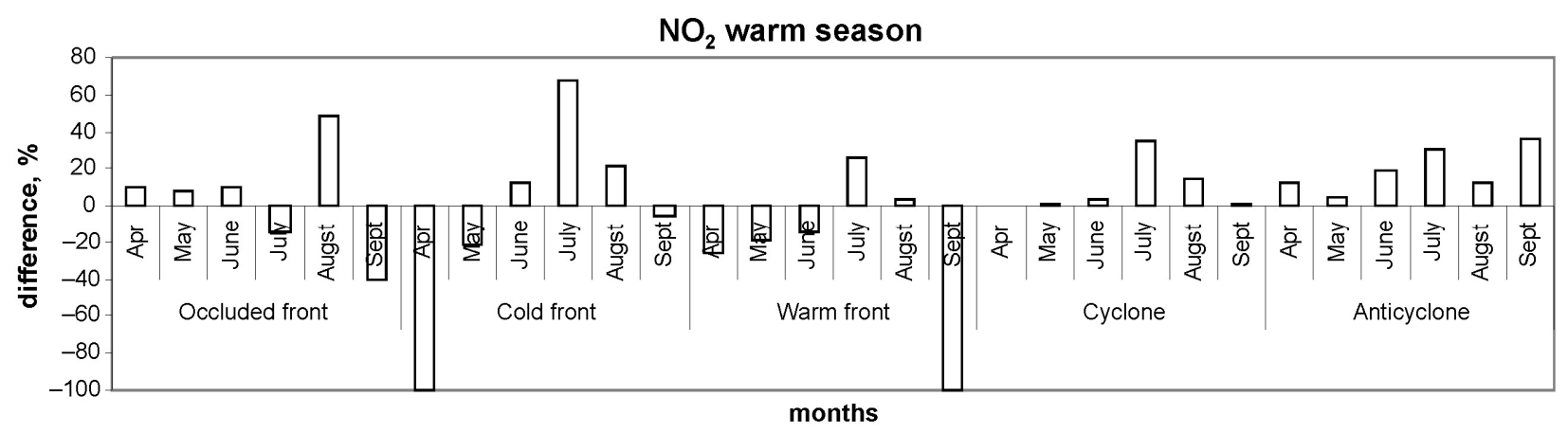

Fig 7. Difference between $\mathrm{NO}_{2}$ three-year monthly average and average concentration during warm season at Preila background station

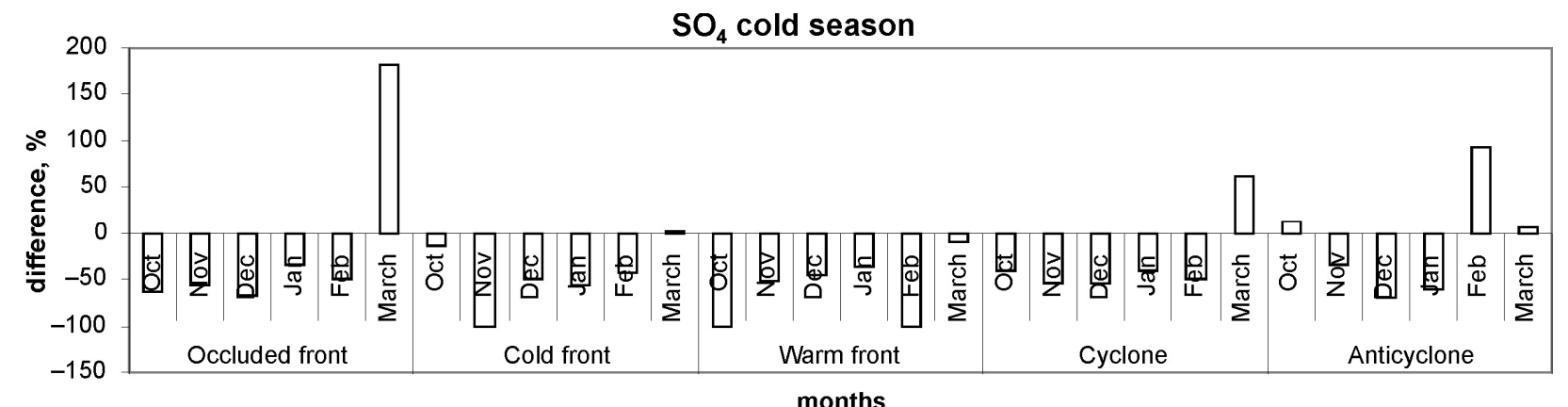

Fig 8. Difference between $\mathrm{SO}_{4}$ three-year monthly average and average concentration during cold season at Preila background station

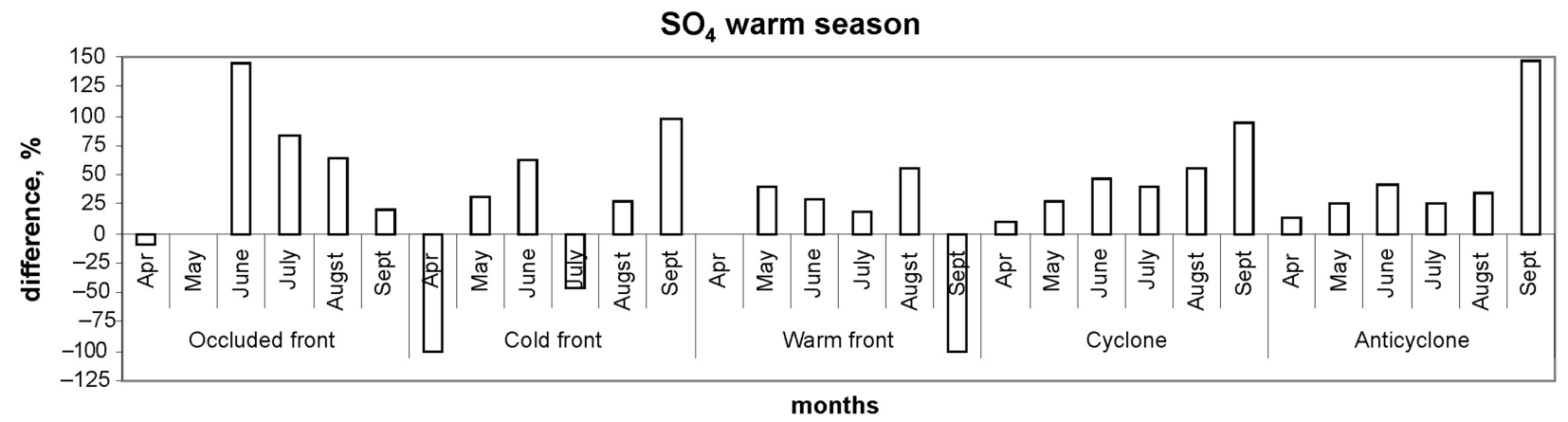

Fig 9. Difference between $\mathrm{SO}_{4}$ three-year monthly average and average concentration during warm season at Preila background station

Distribution of $\mathrm{SO}_{4}$ concentration levels during a cold and warm season was very similar to that determined for $\mathrm{SO}_{2}$ and $\mathrm{NO}_{2}$ concentrations. In most cases $\mathrm{SO}_{4}$ concentration levels did not exceed the three-year monthly average during a cold season. In cases with a given anticyclone the concentration levels were higher than the monthly mean during 3 from 6 months. In addition, it should be mentioned that $\mathrm{SO}_{4}$ concentrations in March exceeded the monthly mean in cases with all the synoptical patterns except a warm front (Fig 8).

The majority of the analysed $\mathrm{SO}_{4}$ concentration level cases during a warm season exceeded the three-year monthly average (Fig 9). During the passage of a cyclone and anticyclone the concentrations were higher than the monthly mean during all the months of a warm season. It is important to emphasize that in May, June and August at all the given analysed synoptical patterns of this study the $\mathrm{SO}_{4}$ concentration levels were higher than or equal to the monthly mean.

\section{Conclusions}

1. The influence of cold, warm and occluded fronts on the high ozone level formation is very similar at both Lithuanian rural stations of Preila and Rūgšteliškès. The influence of all the fronts was more significant during night hours at relatively low ozone levels, and during daily hours at high ozone levels:

- the cold front influence was more significant during night hours at the ozone concentration interval 50$80 \mu \mathrm{g} / \mathrm{m}^{3}$, and during day hours at the ozone concentration of more than $110 \mu \mathrm{g} / \mathrm{m}^{3}$;

- the warm front influence was mostly established during day hours, especially at the ozone concentration level of $50-80 \mu \mathrm{g} / \mathrm{m}^{3}$ and more than $110 \mu \mathrm{g} / \mathrm{m}^{3}$ for Preila, and more than $100 \mu \mathrm{g} / \mathrm{m}^{3}$ for Rūgšteliškès;

- the occluded front influence was clearly established during night hours at the ozone concentration inter- 
val $50-80 \mu \mathrm{g} / \mathrm{m}^{3}$ and more than $110 \mu \mathrm{g} / \mathrm{m}^{3}$ during day hours.

2. The concentrations of $\mathrm{SO}_{2}, \mathrm{NO}_{2}$ and $\mathrm{SO}_{4}$ for the cases with ozone concentration hourly values $\geq 95$ th percentile and influenced by different synoptical patterns are higher than the three-year monthly average during a warm season of the year (from April to September).

3. The concentrations of $\mathrm{SO}_{2}, \mathrm{NO}_{2}$ and $\mathrm{SO}_{4}$ for the cases with ozone concentration hourly values $\geq 95$ th percentile and influenced by different synoptical patterns are lower than the three-year monthly average during a cold season of the year (from October to March).

\section{References}

1. Lietuvos Respublikos vyriausybè. Nutarimas Nr. 130 Dèl valstybinès aplinkos monitoringo 2005 - 2010 metu programos patvirtinimo, Žin., Nr. 19-608, 2005 vasario 7 d.

2. STOHL, A.; TRICKL, T. Experimental evidence for trans-Atlantic transport of air pollution. Newsletter of International Global Atmospheric Chemistry project, No 24, August, 2001, p. 10-12.

3. VESTRENG, V. Review and revision. Emission data reported to CLRTAP. EMEP/MSC-W Technical report 2003. EMEP/MSC-W Note 1, 2003, p. 19.

4. ŠOPAUSKIENĖ, D.; JASINEVIČIENE, D. Time series and trends in atmospheric concentrations of sulphur and nitrogen dioxides in Lithuania in 1981-2001. Environmental and Chemical Physics, 2004, Vol 26, No 3, p. 100-108.

5. BYČENKIENĖ, S.; GIRGŽDIENĖ, R. Influence of air mass long-range transport on ozone concentration at Preila site (Lithuania). Lithuanian Journal of Physics, 2006, Vol 46, No 2, p. 251-259.

6. HJELLBREKKE, A.-G. Transboundary acidification, eutrophication and ground-level ozone in Europe. EMEP Report 1/2004, p. 56.

7. MASAITYTE, M.; RIMKUS, E. Meteorologiniai matavimai Lietuvoje 1777-2002 metais. Geografijos metraštis, 2002, XXXV(1-2), p. 307-321.

8. EMEP manual for sampling and chemical analysis. EMEP/CCC-Report 1/95, NILU, Kjeller, March 1996, p. 264.

9. Finnish Environment Institute, ICP IM Manual.Helsinki: SYKE, 1998, p. 236.
10. TANNER, P. A.; LAW, P. Effects of synoptic weather systems upon the air quality in an Asian megacity. Water, Air and Soil Pollution, May, 2002, Vol 136, No 1-4, p. 105-124.

11. LOKOSHCHENKO, M. A.; ELANSKY, N. F. Dynamics of surface-air pollution during the passage of a cold front. Izvestiya Atmospheric and Oceanic Physics, March, 2006, Vol 42, No 2, p. 148-155.

12. POWLEY, J. F. The impact of climate upon variation in air pollution using a synoptic climatological approach. Dissertation Abstracts International, 1991, Vol 52-09, Section: B, p. 4777.

13. SHANGEDOVA, M.; BURT, T. P.; DAVIES, T. D. Synoptic climatology of air pollution in Moscow. Theoretical and Applied Climatology, 1998, Vol 61, Iss 1/2, p. 85102.

14. ŠIMAITIS, R.; BALTRĖNAS, P. Oro teršalų koncentracija Vilniuje ir jos itaka sveikatingumui. Journal of Environmental Engineering and Landscape Management (Aplinkos inžinerija), 2002, X tomas, Nr. 1, p. Ia-If.

15. Aplinkos oro kokybès tyrimų pasyviaisiais sorbentais programos Panevėžio mieste ataskaita už 2005 m. (2004 0831 sutartis Nr. 4F-49). Aplinkos apsaugos agentūra, Vilnius, 2005, p. 3.

16. RIMKUS, E. Meteorologijos pagrindai. Vilnius, 1998. p. 131.

17. KUNZ, H. ; SPETH, P. Variability of near-ground ozone concentrations during cold front passages : a possible effect of tropopause folding events. Journal of Atmospheric Chemistry, 1997, Vol 28, No 1-3, p. 77-95.

18. EMEP acidifying/eutrophying compounds, 2006. Available from Internet:

<http://www.nilu.no/projects/ccc/emepdata.html>

19. BUKANTIS, A. Lietuvos klimatas. Vilnius, 1994, p. 22-39.

20. CHANG, Y. S. Ground-level ozone and regional transport of air pollutants. Journal of Applied Meteorology, 1977, Vol 16, Iss 11, p. 1127-1136.

21. COMRIE, A. Ch. A Synoptic Climatology of Ozone Concentrations in the Forests of Pennsylvania. Dissertation Abstracts International, 1992, Vol 53-07, Section B, p. 3377.

22. GIRGŽDIENĖ, R.; GIRGŽDYS, A. Ozone Level at two EMEP Stations. EUROTRAC-2: TOR-2 Annual report 2000 , p. $77-82$.

\section{LIETUVOS ORO KOKYBE்S STEBĖSENOS DUOMENŲ IVERTINIMAS TAIKANT SINOPTINĘ ANALIZĘ}

\section{Bimbaitè, R. Girgždienè}

Santrauka

Sinoptinè situacija ir meteorologinès sąlygos turi įtakos atmosferos teršalų pasiskirstymui ir jų formavimosi sąlygoms troposferoje. Judant skirtingiems sinoptiniams dariniams keičiasi meteorologiniai aplinkos parametrai: oro temperatūra, vèjo kryptis ir greitis, kritulių kiekis ir kt., kartu kinta ir oro kokybė tam tikroje teritorijoje. Analizuojamas šilto, šalto ir okliuzijos frontu ịtaka ekstremalioms ozono koncentracijoms Preilos ir Rūgšteliškių oro stebėsenos stotyse 2002-2005 m. Nagrinejjama $\mathrm{SO}_{2}, \mathrm{NO}_{2}$ ir $\mathrm{SO}_{4}$ koncentraciju pokyčiai Preiloje, esant didelėms ozono koncentracijoms slenkant frontams arba esant cikloninei ar anticikloninei cirkuliacijai 2002-2004 m. Analizei pasirinkti atvejai, kai ozono valandinès koncentracijos buvo didesnès arba lygios 95-ajam procentiliui. 95-asis procentilis skaičiuotas kiekvienam mėnesiui atskirai. Kitu teršalų koncentracijų priklausomybė nuo sinoptinių darinių nagrinèta tais pačiais atvejais kaip ir ozono koncentracijos. Atmosferos frontų i taka sąlygiškai mažoms $\left(50-100 \mu \mathrm{g} / \mathrm{m}^{3}\right)$ ozono koncentracijoms buvo nustatyta didesnè nakties valandomis ir šaltuoju metų laiku tiek Preilos, tiek ir Rūgšteliškių stebėsenos stotyse. Kai ozono koncentracijos didesnès nei $100 \mu \mathrm{g} / \mathrm{m}^{3}$, abiejose stotyse reikšmingesnè frontu itaka pastebèta dienos metu ir šiltuoju metų laiku. Abiejose stotyse šaltojo fronto įtaka ozono koncentracijoms nuo $50 \mathrm{iki} 80 \mu \mathrm{g} / \mathrm{m}^{3}$ didesnè nakti, o $\mathrm{O}_{3}$ koncentracijoms nuo $110 \mu \mathrm{g} / \mathrm{m}^{3}$ jo poveikis sustipreja dienos metu. Judant šiltajam frontui, abiejose stotyse dienos metu vyrauja ozono koncentracijos intervalu 
$50-80 \mu \mathrm{g} / \mathrm{m}^{3}$. Šio fronto įtaka dienos metu reikšminga esant $\mathrm{O}_{3}$ koncentracijoms nuo $100 \mu \mathrm{g} / \mathrm{m}^{3}$ Rūgšteliškèse ir nuo $110100 \mu \mathrm{g} / \mathrm{m}^{3}$ Preiloje. Okliuzijos fronto poveikis ozono koncentracijoms abiejose stotyse buvo reikšmingesnis nakties metu 50-80 $\mu \mathrm{g} / \mathrm{m}^{3}$ intervalu, o dienos metu - kai $\mathrm{O}_{3}$ koncentracijos buvo didesnès nei $110 \mu \mathrm{g} / \mathrm{m}^{3} . \mathrm{SO}_{2}, \mathrm{NO}_{2}$ ir $\mathrm{SO}_{4}$ koncentracijoms (analizuoti atvejai, kai ozono koncentracijos buvo didesnès arba lygios 95-ajam procentiliui) didesnè sinoptinių darinių įtaka pastebėta šiltuoju metų laiku.

Reikšminiai žodžiai: sinoptiniai dariniai, oro kokybė, frontas, ciklonas, anticiklonas, ozonas, $\mathrm{SO}_{2}, \mathrm{SO}_{4}, \mathrm{NO}_{2}$.

\section{ОЦЕНКА ДАННЫХ МОНИТОРИНГА КАЧЕСТВА ВОЗДУХА В ЛИТВЕ С ПРИМЕНЕНИЕМ СИНОПТИЧЕСКОГО АНАЛИЗА}

\section{В. Бимбайте, Р. Гиргждене}

Р е $з$ ю м е

Проанализирована связь между синоптическими объектами и уровнем концентрации разных загрязнителяй. За период 2002-2005 гг. для каждого месяца проанализированы случаи, когда среднечасовая концентрация озона превышала или была равной 95-му процентилю. Полученные результаты сгруппированы в семь групп уровней концентрации и проанализированы согласно синоптическим объектам (холодные и теплые фронты, фронт окклюзии). Исследована связь между газовой $\left(\mathrm{SO}_{2}, \mathrm{NO}_{2}\right)$, а также аэрозольной $\left(\mathrm{SO}_{4}\right)$ примесями и синоптическими объектами отдельно во время теплых и холодных сезонов.

Влияние холодных и теплых фронтов и фронта окклюзии на формирование высокого уровня озона одинаково на обеих станциях мониторинга в Литве: в Прейле и Ругштелишкес. Влияние фронтов было существеннее в ночное

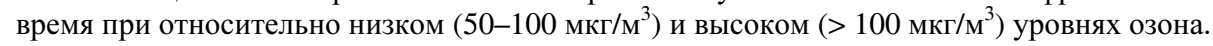

Были проанализированы случаи с высокой концентрацией озона, с привлечением данных об изменениях в это время концентрации газов $\mathrm{SO}_{2}, \mathrm{NO}_{2}$ и составляющей аэрозоля $\mathrm{SO}_{4}$. Влияние различных синоптических объектов было сильнее выражено во время теплого и слабее во время холодного сезонов.

Ключевые слова: синоптические объекты, качество воздуха, фронты, циклон, антициклон, озон, $\mathrm{SO}_{2}, \mathrm{SO}_{4}, \mathrm{NO}_{2}$.

Vilma BIMBAITE். Master student, Dept of Environmental Protection, Vilnius Gediminas Technical University (VGTU). Bachelor of Science (geography), VU. Research interests: air quality, pollutant transport due to synoptical patterns.

Raselė GIRGŽDIENĖ. Dr, Dept of Physics, Vilnius Gediminas Technical University (VGTU).

Doctor of Science (environmental physics), 1986. Publications: more than 60 scientific publications. Research interests: air quality, pollutants transport and transformation, indoor and outdoor problems, monitoring, ozone problem, environmental assessment. 